\author{
Danuta Wajsprych* \\ Olsztyn
}

\title{
Wolność jako fundamentalna przesłanka liberalnej filozofii wychowania Józefa Tischnera
}

\section{Uwagi wstępne}

Józef Tischner jako wybitny autor polskiego dialogu od samego początku był zaangażowany społecznie, odważnie poszukując odpowiedzi na pytania: kim jest człowiek?; jaką rolę odgrywa nadzieja w jego życiu?; co to jest prawda? Pisał o problemach ludzkich i pracował nad ludzką nadzieją, czyniąc to wszystko z myślą o bliźnich. „Dla ludzi pracujących z ludźmi i nad ludźmi wiara w człowieka jest warunkiem wejścia w twórczy dialog, jakim jest wychowanie". . Jego cel można osiagnąć, kiedy skupimy się przede wszystkim na trzech wartościach: wolności, prawdy i dobra.

Rozumiejąc filozofię wychowania jako filozofię kultury ${ }^{2}$, warunki wychowania do dobra i w dobru znajdują swój sens nie w zastosowaniu,

* Dr hab. Danuta Wajsprych jest profesorem Olsztyńskiej Szkoły Wyższej im. J. Rusieckiego w Olsztynie.

${ }^{1}$ M. Piaskowski-Majzel, P. Kołodziński, Aktualność Tischnera, Szczecin 2008, s. 20.

${ }^{2}$ Filozofia kultury jako filozofia konstytucji sensu to filozofia podstawy i możliwości uprawomocnienia poszczególnych dziedzin przedmiotowych. Nie jest więc dziedziną pokrewną pedagogice ze względu na wspólny ,,interes humanistyczny”. Jest ona zakorzeniona i zawarta w samym sensie pojęcia paidei i niejako z niej wyrasta. Filozofia wychowania i kultury zatem to pewna organiczna jedność skupiona w tym źródłowym sensie. Por. M. J. Siemek, Myśl drugiej połowy XX wieku, w: tenże, Filozofia, dialektyka, rzeczywistość, Warszawa 1982, s. 54. 
lecz w rozjaśnianiu praxis, a także w namyśle nad przyjętym sensem bycia człowieka. Zadaniem, jakie sobie stawiam w tej wypowiedzi, jest uświadomienie jakiegoś etycznego a priori w wychowaniu, w którym nader często zapomina się o pochodności czy niezupełności projektowanych przez nie sensów bycia człowieka. Będę zatem starała się odpowiedzieć na pytanie: co musi wydarzyć się w ramach codziennego zatroskania o wychowanka, żeby mógł dokonać się w nim zwrot do odkrywania siebie jako człowieka dobrego, a owo etyczne a priori ujmę w formę zasady wychowania do wolności ${ }^{3}$. W przestrzeni wychowania do wolności wyróżniam za Tischnerem cztery ścieżki (transgresję, transcendencję, aproksymację, supererogację), którymi może podążać wychowanek, a wraz z nim wychowawca, jeśli tylko będą chcieli rozwijać w sobie potencjalność czynienia dobra i wychowania w dobru.

\section{Wychowanie do wolności}

Nieodłącznym kontekstem faktycznych wyborów człowieka jest wolność ${ }^{4}$ i nierozłączna z nią odpowiedzialność. Gdy mówimy o istnieniu i rozwoju człowieka jako osoby, zwracamy uwagę na specyficzne, osobowe wymiary jego istnienia. Należą do nich nade wszystko: rozumność i wolność.

${ }^{3}$ Definicję zasady przyjmuję za Kazimierzem Sośnickim, który uznawał zasadę wychowania za pewną odmianę szerszego pojęcia „normy”, ale niezależnej od prawa (w sensie logicznym, przyczynowo-skutkowym), lecz powiązanej z aksjologią, wartościami bezwzględnymi i względnymi. W takim ujęciu zasada jest odzwierciedleniem pewnych ogólnych prawidłowości występujących w procesie wychowania, które nie muszą być konieczne ani prawdziwe, lecz powinne i słuszne jako rezultat naszego własnego wyboru i postanowienia. O ich trwałości i stabilności decyduje treść przyjętej zasady wychowania jako podstawy przyszłego działania oraz wartość jako motyw tego działania. Zob. K. Sośnicki, Istota i cele wychowania, Warszawa 1964, s. 149-152; tenże, Zagadnienie najogólniejszych zasad wychowania, „Ruch Pedagogiczny" 6 (1969), s. 727-750.

${ }^{4}$ Wolność definiuję w punkcie wyjścia semantycznie w myśl filozofii liberalnej jako wartość autoteliczną, nie zaś jako coś, co jest pożądane dlatego, że umożliwia osiąganie innych dóbr. Swoisty kult wolności znajduje wyraz w tezie głoszącej istnienie swobód podstawowych, takich jak wolność osobista, nietykalność cielesna, wolność wyznania, sumienia i stowarzyszania się oraz w niechęci wobec kolektywizmu jako przekonania o dominacji tego, co wspólnotowe nad tym, co jednostkowe. Wolność dla liberałów jest po prostu wolnością od zewnętrznego przymusu, pozwalająca jednostce na wybór tego, co chce robić (wolność negatywna), nie zaś wolnością do robienia czegoś, co z góry zostaje uznane za dobre (wolność pozytywna). Zob. Z. Drozdowicz, Liberalizm europejski, Poznań 2005. 
Zdaniem J. Maritaina, błędem współczesnych jest brak rozgraniczenia dwu typów wolności: wolności wyboru (akcentowanej i absolutyzowanej przez egzystencjalistów, ekstremalny indywidualizm i ideologiczny liberalizm) i wolności wewnętrznej. Wolność wyboru jest wolnością jedynie zewnętrzną, pomijającą lub pomniejszającą rolę wolności wewnętrznej człowieka i w konsekwencji przeczącą istnieniu wolności woli, co w rezultacie pomija kwestię odpowiedzialności człowieka. Wolność zewnętrzna od przymusu (wolność wyboru) jest niezbywalnym prawem człowieka, ale nie jest równoznaczna z wolnością wewnętrzną, której osiagnnięcie wymaga długotrwałego wysiłku moralnego i opowiedzenia się człowieka za dobrem (wolność do). Zdaniem J. Maritaina, prawdziwą wolność wewnętrzną można osiagnąć jedynie poprzez miłość ${ }^{5}$. Taka wolność to umiejętność samokierowania sobą, poczucie odpowiedzialności za życie swoje i innych ludzi oraz zdolność moralnego doskonalenia się. Osoba jako byt dla siebie w ujęciu Tischnera uznaje potrzebę i nieodzowność obu typów wolności: zewnętrznej i wewnętrznej.

W Tischnerowskiej liberalnej filozofii wychowania wolność jest sposobem istnienia dobra ${ }^{6}$. Dobro rodzi się z wolności. Wolność jest zasadą przyswajania osoby dobru i dobra osobie. Ostatecznie to rozumowanie prowadzi Tischnera do sformułowania fundamentalnej dla jego filozofii wolności tezy, według której wolność jest sposobem istnienia dobra, przy czym istnienie jest tu rodzajem metafory - należy je rozumieć nie ontologicznie, lecz agatologicznie. Pisze:

Dobro nie może być dobre z musu, z konieczności. [...] Dobro, aby być dobrem, musi samo chcieć być dobrem. [...] Słowo musi nie oznacza jednak konieczności logicznej, lecz dramatyczną. [...] Wewnętrzne życie osoby jest konkretnym odbiciem dramatu dobra. To właśnie osoba, konkretny człowiek, aby być do-

${ }_{5}^{5}$ Por. J. Maritain, Humanizm integralny, Londyn 1960, s. 20-29.

6 „Dobro zwie się po grecku agaton. Logos znaczy to, co rozumne, mądre. Powiemy więc: spotkanie jest otwarciem agatologicznego horyzontu doświadczenia międzyludzkiego. Horyzont agatologiczny to taki horyzont, w którym wszystkimi przejawami innego i moimi włada swoisty logos - logos dobra i zła, tego co lepsze i co gorsze, wzlotu i upadku, zwycięstwa i przegranej, zbawienia i potępienia. Na czym to polega? Tego przy spotkaniu jeszcze nie wiem. Wiem jednak, że gdy spotykam, zawsze o coś takiego chodzi”. J. Tischner, Filozofia dramatu, Kraków 2006, s. 46. Rozpoznając kategorię wolności w liberalnej filozofii wychowania J. Tischnera, będę się posługiwać terminem «pedagogia agatologiczna», gdyż w istocie tenże uznawał, że wolność jest warunkiem zaistnienia dobra. Por. J. Tischner, Spór o istnienie człowieka, Kraków 1998, s. 315-318. 
brym, nie może nie chcieć być dobrym. Chcenie dobra musi być wolne. Wolność wyraża i przyswaja dobro?.

Wolność jest tu rozumiana nie jako prosty wybór pomiędzy dobrem a złem, sięga dalej niż racjonalny wybór. W pedagogii Tischnera wolność przybiera postać nadziei na dobro, stąd jest ona przede wszystkim przyswajaniem i wspaniałomyślnym wyrażaniem dobra. „Dramatyczność” sytuacji wychowawczej polega tu w pierwszym rzędzie nie na opozycji istnieć-nieistnieć w sensie ontologicznym, ale na tym, że owo „być albo nie być” człowiekiem dobrym pojawia się w przestrzeni aksjologicznej. Można bowiem istnieć i być martwym moralnie w swoim wnętrzu i można odchodzić z tego świata z poczuciem wygranej. Nie zawsze niszczy i zabija człowieka śmierć biologiczna. Człowiek umiera także i wtedy, kiedy miejsce nadziei zostaje wypełnione rozpaczą. Stąd ocalenie nadziei jest głównym motywem i celem Tischnerowskiej filozofii wychowania. Nadzieja jest elementem dynamicznym, dzięki któremu możliwy staje się wybór dobra, pomimo doświadczanego zła. Dobro bowiem jest zawsze bliższe naszym nadziejom, mimo że zło jest bliższe naszemu doświadczeniu.

Ostatecznie dialog okazuje się dramatem za sprawą wolności, która przysługując człowiekowi, czyni go osobą. I chociaż człowiek jest istotą skończoną - zwłaszcza w wymiarze ontycznym, jako byt pośród bytów - to jednak w perspektywie dialogu, będąc obdarzony wolnością, staje się on jego pełnoprawnym uczestnikiem. Stąd wychowanek staje się partnerem, którego odpowiedź, choć późniejsza niż pytanie wychowawcy, okazuje się równie ważna. Wolność wychowanka, osoby-która-odpowiada, jest bowiem - jak poucza Tischner - miejscem niedostępnym nawet dla $\mathrm{Boga}^{8}$. Okazuje się, że ze względu na wolność będącą atrybutem bycia osobą - dobro jest również wolne i - mimo że jest też źródłem wolności - powstrzymuje się od przemocy. Inaczej dzieje się ze złem, które grożąc, strasząc lub obiecując - czyni zamach na osoby, godząc w ich wolność.

Tischnerowska filozofia wychowania dowodzi zatem, że może być rozwijana jedynie w przestrzeni aksjologicznej. Człowiek - podmiot dramatu to ten, który podejmuje spór rozgrywający się w obszarze wartości etycznych. Spór ten przebiega nie wedle rygorów rządzących bytem, lecz toczy się stosownie do etycznych wyborów dokonywanych przez wolnego człowieka. I o ile „logika" metafizyki posiada strukturę monologiczna, o tyle filozofia

\footnotetext{
7 J. Tischner, Spór, s. 317-318.

8 Tenże, Apostolstwo odzyskanej wolności, „Etyka” 28 (1995), s. 117.
} 
dramatu - nawiązująca bezpośrednio do sensów, jakie niesie człowiekowi objawienie i spotkanie z Drugim - przeniknięta jest dialogicznością.

I jeszcze raz sens pytania i odpowiadania, pojawiając się $\mathrm{w}$ aspekcie wolności tych, którzy to czynią (wychowawca-wychowanek), ujawnia swój dramatyczny wymiar. Odpowiadanie daje człowiekowi szansę, by uznając „gdzie jesteś” uzmysłowił sobie swój osobowy status. Osoba to ten, kto odpowiadając uznaje, że jest odpowiedzialny. Do tego uznania potrzebny jest czyn - udzielenie odpowiedzi. Odpowiedzialność bierze się zatem w agatologii z odpowiadania. Odpowiadanie nie jest konsekwencją arbitralnego nakazu, lecz przywilejem. Ilekroć wychowanek z niego korzysta, tylekroć afirmuje swoje człowieczeństwo. Dlatego, jak stwierdza Tischner, ,pytanie «gdzie jesteś?» ma moc budzenia ze snu. Dzięki niemu ludzie zjawiają się dla siebie".

Wolność ma w Tischnerowskim projekcie etycznym wartość jedynie wówczas, gdy jest dialogiczna: moja wolność nigdy nie będzie wolnością dojrzałą bez wolności Innego. Wolność nie ma w sobie nic z egoizmu, indywidualizmu. Wręcz przeciwnie, przynależy ona wprost do „substancji etycznej" człowieka i jego wspólnoty ${ }^{10}$. Dlatego, tak jak istotą człowieka jest wolność, tak też istotą oddziaływania pedagogicznego - w myśl takiego podejścia - jest wychowanie do wolności. Ta zaś zawsze jest wolnością „od” oraz ,do".

Wolności nie można się zatem obawiać, upatrując w niej zagrożenie, lecz należy przygotować do niej, to znaczy wychować do wolności. Wolność wymaga wychowania, ale autentyczne wychowanie jest zawsze wychowaniem wolnego człowieka. Wolność jest tajemnica. Doświadczamy jej, gdy czynimy coś w sposób wolny. Wychowanie do wolności musi być świadome potrzeby stworzenia warunków, w których wychowanek będzie podejmował własne decyzje, będąc odpowiedzialnym ,za” i ,wobec”, doświadczając własnej tożsamości. Ujawniająca się bowiem w wolności tożsamość zakłada moment przejścia przez samotność, pewnego rodzaju separacji. Własnej tożsamości doświadczamy w tych wyborach i decyzjach, w których jesteśmy samotni, niezastępowalni. Wychowanie do wolności jest więc wychowaniem do bycia odważnym ${ }^{11}$.

9 Tenże, Filozofia, s. 86.

10 Tenże, Ksiądz na manowcach, Kraków 2002, s. 208.

11 T. Gadacz, O umiejętności życia, Kraków 2009, s. 143-161. Proponowana przez Gadacza koncepcja wychowania do wolności podkreśla jej afirmację w procesie egzystencjalnej dyspozycji wyboru. Za kluczową jednak uznaje autor kategorię odpowiedzialności. Zawsze 
W Tischnerowskiej filozofii wychowania wolność wobec wartości ma dwie możliwości: dobro jako bezinteresowne urzeczywistnianie wartości lub zło, pełniące funkcję kuszenia i prowadzące ostatecznie do deprecjacji wartości. Przejście od wolności do wartości następuje w wyborze, łączącym potencjalność i aktualizację. Wytycza tym samym kierunek, który daje możliwość przejścia od posiadanej wolności do urzeczywistnianej wartości (dobra). Dopiero wybór sytuuje człowieka w świecie etyczności, ponieważ ten, kto w akcie preferowania lub deprecjonowania coś wybiera, czyni użytek ze swej wolności i urzeczywistnia określone wartości. Wolność umożliwia dokonywanie suwerennych wyborów, te zaś potwierdzają lub urzeczywistniają jakieś wartości, które choć mają wartość samą w sobie, to jednak, jak się wydaje, ich znaczenie wyraża się przede wszystkim ze względu na kogoś lub cośt ${ }^{12}$.

Dobro wypełniające ideę wychowawcy wspaniałomyślnego, wrażliwego moralnie i odpowiedzialnego wytycza przede wszystkim jakość przestrzeni międzyludzkiego kontaktu i choć jest wartością samą w sobie, to jednak jej faktyczny sens jest sensem ,ze względu na" wychowanka, dzięki któremu może zaistnieć dialogiczna przestrzeń wykraczania „ku”.

Dobrowolne czynienie dobra jest aktualizacją nieustannej progresji i otwartości w wychowaniu, które wytyczają z kolei horyzonty ${ }^{13}$ osobowego rozwoju. Owe horyzonty osobowego rozwoju J. Gara ${ }^{14}$ ujmuje w postaci trzech wymiarów: transgresji, transcendencji i aproksymacji. Każdy wybór wyłania bowiem nowe możliwości, wcześniej niedostępne dla ludzkiego spojrzenia (aproksymacja), pozwala przekroczyć siebie i prowadzi dalej (transgresja) oraz nakłada nieredukowalną odpowiedzialność „wobec” i „za”, zwracając nas tym samym „ku” (transcendencja). Są one wyrazem egzystencjalnej dyspozycji wyboru wolności, dobra i odpowiedzialności ${ }^{15}$.

bowiem chodzi o odpowiedzialną wolność, odpowiedzialność za urzeczywistniane wartości oraz odpowiedzialny wybór.

12 Tamże, s. 147.

13 Pojęcia horyzontu nie traktuję jako zwykłego ozdobnika, lecz jako odwołanie do przyjętej w tej wypowiedzi fenomenologiczno-hermeneutycznej perspektywy metodologicznej. Horyzont stanowi tu zatem to, co z jednej strony ogranicza poznanie, jednak z drugiej strony, stanowi niezbędny warunek rozumienia, pojmowanego jako to, co jest wyznaczane przez ogląd dany zawsze z jakiejś określonej perspektywy (nie ma więc, jak sugeruje „teoria słaba”, bezpośredniego oglądu ,jako takiego”, widzenia, które dokonywałoby się z np. „boskiego” punktu widzenia).

14 J. Gara, Pedagogiczne implikacje filozofii dialogu, Kraków 2008, s. 228.

15 Tamże, s. 229. 
Transgresję, której wyrazem jest ruch „od”, traktować można zatem jako wymiar plasujący się w obrębie założeń teoretycznych wychowania do wolności, transcendencję, wyrazem której jest ruch „ku”, jako przynależną do założeń teleologicznych tej pedagogii, aproksymację zaś, wyrazem której jest sposób, w jaki wydarza się przekraczanie siebie (ruch „od”) oraz wykraczanie „ku” czemuś, jako otwarcie się na coś, co bliżej nieokreślone, niedostępne dla zmysłów. Do wymienionych wymiarów osobowego rozwoju dołączam wymiar supererogacji, gdyż jeśli dobro czyni się przedmiotem nakazu, odrywa się je od doświadczenia wolności ${ }^{16}$. Supererogację uznaję jednocześnie za wspaniałomyślność $i$, ze względu na nieobowiązkowe jego czynienie, jako także miłosierność czy hojność. Nadajemy tym samym dobru znaczenie czynu nadobowiązkowego, element naddatku, „czegoś więcej" niż normatywnie konieczne.

Wszystkie cztery kategorie zostały znakomicie rozpoznane jako rudymenty pedagogii dialogu ${ }^{17}$, zatem $\mathrm{w}$ tym fragmencie wypowiedzi pominę ich opis, a skoncentruję się na wolnościowych uprawomocnieniach horyzontu osobowego rozwoju.

\section{Ścieżka pierwsza: Transgresja}

Przyjmując, że charakterystyczny rys transgresji człowieka uwidacznia się w ukierunkowaniu na czynności ,poza” - poza to, co jest, ku temu, co możliwe, poza to, co zastane, ku temu, co w potencjale drzemiące i uśpione ${ }^{18}$, poza to, czym człowiek nie jest, ku temu, kim może być ${ }^{19}$, to agatologii jako podstawy projektu etycznego wychowania nie da się raczej ulokować w tak zwanej etyce powinności, lecz po stronie etyki autentyczności, rozumianej tu jako moralność życia codziennego, bardziej wieloznacznej i pełnej niepokoju ${ }^{20}$ niż etyka normatywna. Ta bowiem opiera się na normie, jest określona i zamknięta w system. W etyce powinności nieodłącznie króluje logika, według której wychowawca dokładnie wie, co ma czynić. Tymcza-

16 J. Tischner, Myślenie wedtug wartości, Kraków 1993, s. 495.

17 Zob. m.in. J. Rutkowiak, Pytanie, dialog, wychowanie, Warszawa 1992; i ostatnio, E. Dąbrowa, D. Jankowska (red.), Pedagogika dialogu. Dialog warunkiem rozwoju osobowego i społecznego, Warszawa 2008; J. Gara, Pedagogiczne implikacje filozofii dialogu, Kraków 2008.

18 J. Kozielecki, Koncepcja transgresyjna człowieka, Warszawa 1987, s. 14.

19 Tamże, s. 13.

${ }^{20}$ Ch. Taylor, Etyka autentyczności, thum. A. Pawelec, Kraków 2002. 
sem etyka autentyczności akcentuje moralny charakter wychowawcy, jego wewnętrzne zintegrowanie, zrównoważenie i zwyczajnie ludzki osąd moralny, pozostający poza imperatywem powinności ${ }^{21}$.

W procesie wychowania, który ma się odbywać w perspektywie agatologii, przydatność etyki normatywnej, wyznaczającej obiektywne warunki zaistnienia dobra i zła, nie wydaje się przekonująca. Wszak dobro i zło wydarzają się między wychowankami, a także między wychowawcą i wychowankiem, w zawiłościach i napięciach ludzkich spraw. Dobro jako czyn moralny, w przeciwieństwie do czynu normatywnego, to powrót do prostoty (odruchów dobra codziennego), tego, co żywe i na ludzką miarę, gdzie jest także miejsce na słabość (np. zło). Moralność w perspektywie agatologii jest najgłębszym wyrazem tęsknoty za bezpośredniością. Etyka agatologiczna jest zatem etyką dóbr, a nie monoparadygmatyczną etyką imperatywów. Jest to etyka losów wychowanka, uwarunkowań, temperamentów, odmiennych kultur. Odkrywa świat ludzkich uczuć i poruszeń - wrażliwość. Dobro zatem rozumiane transgresyjnie pozwala zmieniać i modyfikować strukturę tej wrażliwości, pozwala też na podejmowanie wciąż na nowo tego, czego nie było, jakości i kategorii w wychowaniu, które zostały zapomniane, lub w ogóle nie były obecne. Transgresja dobra wyraża się najpełniej, powtórzmy, w aktach nabywania nowych doświadczeń i form wyrazu swego bycia, ujawniających się w moralności codziennych relacji.

\section{Ścieżka druga: Transcendencja}

Powracając raz jeszcze do poczynionego rozróżnienia na etykę normatywną oraz na etykę autentyczności (moralność dnia codziennego) oraz lokowania agatologii w przestrzeni tej drugiej, owo lokowanie przeczyłoby zaistnieniu dialogicznej zasady transcendencji jako ruchu wykraczającego „ku” Dobru nieskończonemu nieujmowalnemu (Bogu). Tak ujmowana transcendencja potrzebuje bowiem metafizyki fundamentu, pewności kształtującej ,pedagoga jednej drogi” w opozycji do „pedagoga wielu dróg”, który w swych codziennych wychowawczych oddziaływaniach podąża za etyką autentyczności ${ }^{22}$. Czy możliwe jest zatem przezwyciężenie tej swo-

${ }^{21}$ Zob. P. Kostyło, Wykluczanie jako problem filozofii edukacji. Komentarz do badań empirycznych, Kraków 2008, s. 171.

22 Zob. J. Rutkowiak, Odmiany myślenia o edukacji. Mapa konturowa, w: tenże (red.), Odmiany myślenia o edukacji, Kraków 1995, s. 11-53. 
istej aporii? Otóż zdaje się, że osadzenie pedagogii agatologicznej w polu myśli słabej stwarza tę możliwość. Gdyby bowiem ująć powyższy problem w kategoriach zachowania tożsamości (potrzeba ,jednej drogi”) i otwarcia na różnorodność (potrzeba „wielu dróg”), to przezwyciężeniem antynomii i napięcia mogłaby być Vattimowska formuła „myśli słabej”. Umożliwia ona wszakże ujęcie struktury antropologii życia na dwóch poziomach dyskursu, rozpatrującego człowieka hic et nunc oraz in potentia, nie pozbawiając go ani podstaw formowania się spójnej tożsamości (dewaluowanych przez paradygmat ,epistemologicznej niepewności”), ani różnorodności (zagrożonej paradygmatem ,epistemologicznej pewności”), lecz dając podstawy do koherentnego formowania się tożsamości w świecie równouprawnionej wielości.

Pierwszy poziom dyskursu, o którym mowa, obejmuje przedzałożeniowość i preferencje, określony światopogląd, wyobrażenie o Absolucie, człowieku i świecie. Kategoria prawdy na tym poziomie nie jest rozstrzygalna kognitywnie, nie odnosi się do faktów, lecz do języka egzystencji, jest własną mową życia. Jak chce „myśl słaba”, prawda „wydarza się”, jest więc subiektywna i choć jest nierozstrzygalna kognitywnie, to nieoznacza, że nie istnieje obiektywnie. Tu też konstytuują się najgłębsze pokłady tożsamości.

Drugi poziom natomiast jest obszarem współistnienia ukonstytuowanej już różnorodności, gdyż mamy tu do czynienia z założeniowością i wyborem orientacji, dokonanym przez dojrzała, ukonstytuowana, niepowtarzalną tożsamość jednostki, opartej na przesłankach z pierwszego poziomu, to jest wolitywnej preferencji i przedzałożeniowości. Na tym poziomie możliwe już są rozstrzygnięcia kognitywne i intersubiektywne weryfikacje, prowadzące do rozpoznania wspólnych znaczeń i umowy społecznej. Ich moc nie uprawnia jednak do rewidowania fundamentów jednostkowej tożsamości. Nie o prawdę zatem chodzi na tym poziomie, lecz o praktyczną użyteczność intersubiektywnych odniesień między wychowawcą a wychowankiem. I w tym momencie pojawia się miejsce dla transcendencji poprzez wspólne uobecnianie wartości i wartościowania w procesie wychowania ${ }^{23}$.

Choć sensu tej prakseologicznej przestrzeni wychowania nie da się sprowadzić do prostej formuły, to nie oznacza, że ona nie istnieje. Implikowana jest właśnie świadomością transcendencji, wykraczania „ku” temu, co nieujmowalne, zaakceptowania perspektywy nieskończoności, która uczy pokory. Zasada transcendencji w pedagogii agatologicznej uczy bowiem, że to, co dane w zewnętrznym oglądzie, jest tylko jakimś fragmentem złożonej

23 J. Gara, dz. cyt., s. 239. 
rzeczywistości, której nie da się ująć jako miarowej i symetrycznej „matrycy wszystkiego" 24 .

\section{Ścieżka trzecia: Aproksymacja}

Sposobem zaistnienia dobra jako aproksymacji w procesie wychowania będzie logika ciagłych jego przybliżeń, powtarzalności dobra w dojrzewaniu do człowieczeństwa, otwarcie się na dobro jako coś, co bliżej nieokreślone, niedostępne dla zmysłów. Wojtyła nazywa to perfekcjoryzmem ${ }^{25}$. Logika aproksymacji dobra jako czynu ujawnia dwojaki charakter tego czynu. $\mathrm{Z}$ jednej strony jest on przechodni, bo ze względu na swą intencjonalność wychowawca obdarza dobrem wychowanka. Dobro czynu „przechodzi” na niego, zostawiając w nim ślad dobra. $Z$ punktu widzenia aproksymacji o wiele ważniejszy jest nieprzechodni charakter czynu dobrego. Każdorazowo ponawiany czyn dobry wychowawcy zostawia przede wszystkim ślad dobra w nim samym, umacniając i utwierdzając w ten sposób jego tożsamość osobową. „W wymiarze wewnętrznym osoby bowiem czyn dobra przemija i nieprzemija zarazem. Odnosi skutek trwalszy niż on sam, ze względu na swój skutek nieprzechodni uprzedmiotawia się w osobie. Człowiek staje się lepszy poprzez skutki nieprzechodnie swych czynów"26.

Każdy dobry czyn objawia strukturę człowieka w ogóle, czyli naturę ludzkiej osoby. Na podstawie takiego czynu Tischner w swej agatologii sformułował między innymi twierdzenie, że każdy człowiek może dążyć do dobra, jeśli tylko zechce, może się poprzez dobro spełniać (realizować) lub przez czynione zło zdegradować (zdeformować). Tak więc dobro, będąc głównym desygnatem moralności, jest zarazem głównym przedmiotem etyki w pedagogii agatologicznej. Aproksymacja dobra w wychowaniu, w perspektywie teorii skutków przechodnich i nieprzechodnich czynu, wyraźnie ujawnia, jak poprzez czynione dobro następuje samourzeczywistnienie się sprawcy dobra, to jest wychowawcy. Czyniąc dobro wychowankowi, samo-

${ }^{24}$ Zob. F. Rosenzweig, Nowe myślenie. Kilka uwag ex post do Gwiazdy Zbawienia, w: tenże, Gwiazda zbawienia, tłum. T. Gadacz, Kraków 1998.

${ }^{25}$ Perfekcjoryzm w pismach K. Wojtyły oznacza stawanie się człowieka coraz lepszym poprzez każdorazowo powtarzany dobry czyn. Zob. K. Wojtyła, Osoba i czyn, w: T. Styczeń (red.), Osoba i czyn oraz inne studia antropologiczne, Lublin 1994.

26 Tamże, s. 195. 
udoskonala się, samorealizuje i czyni siebie coraz lepszym. Te same procesy zachodzą w wychowanku na skutek przechodniego charakteru dobra.

Warto w tym miejscu jeszcze raz powtórzyć, że esencję dobra w Tischnerowskiej pedagogii agatologicznej stanowi czysta wola czynienia/dawania dobra bez warunków i oczekiwania wzajemności. Mimo pozorności „,czynienia czegoś za darmo", a więc rodzaju straty, pozbawienia się czegoś istotnego, dobro, wychodząc od podmiotu w swej istotowej treści, wraca do tego samego podmiotu, przysparzając mu wartości (w myśl zasady: co czynisz drugiemu, zawsze do ciebie wróci) ${ }^{27}$. Chcę utrzymywać, że sens aproksymacji dobra w wychowaniu, przybliżania się do człowieczeństwa rozumianego jako perfekcjoryzm, wzmacnia się każdorazowo przy przekraczaniu siebie (transgresja) i wykraczaniu ku temu, co względem nas samych zewnętrzne (transcendencja).

\section{Ścieżka czwarta: Supererogacja}

Rozważania nad wychowaniem do wolności, pozbawionym imperatywu konieczności i obowiązku, powinny być uzupełnione w tym miejscu analizą pojęcia supererogacji ${ }^{28}$. Uznając, że wolność jest sposobem istnienia dobra (przypomnijmy słowa Tischnera: ,jeśli dobro czyni się przedmiotem nakazu, odrywa się je od doświadczenia wolności" ${ }^{29}$ ), uznajemy jednocześnie jego wspaniałomyślność i, ze względu na nieobowiązkowe jego czynienie, także miłosierność czy hojność. Nadajemy tym samym dobru znaczenie czynu nadobowiązkowego, element naddatku, „czegoś więcej” niż normatywnie konieczne. Nikt wszak nie wymaga od nas, byśmy byli miłosierni, wielkoduszni czy hojni. Jeśli tacy jesteśmy, to świadczymy wspomniany naddatek, robimy coś, czego nie musimy. Ten model postępowania moralnego nosi miano supererogacji ${ }^{30}$.

Jednakowoż uznanie dobra jako czynu supererogacyjnego nie jest takie oczywiste, jakby się wydawało przy pierwszej intuicji. Analiza myśli Tischnera doprowadza bowiem do wniosku, że chcąc uzgodnić ideę supererogacji s. 77.

${ }^{27}$ Zob. W. Chudy, Pedagogia godności. Elementy etyki pedagogicznej, Lublin 2009,

${ }^{28}$ Szczegółowej analizy supererogacji dokonał Andrzej Kaniowski. Zob. tegoż, Supererogacja. Zagubiony wymiar etyki, Warszawa 1999.

29 J. Tischner, Myślenie, s. 495.

${ }^{30}$ P. Kostyło, dz. cyt., s. 173. 
względem czynionego dobra, należałoby ją nieco zmodyfikować i uznać za supererogację dobro realizujące pewnego rodzaju powinność ontologiczna, zwłaszcza jeśli zestawia się dobro ze złem (opozycja ta wyraźnie wskazuje na wybór dobra jako powinności). W takim ujęciu dobro uznać można za czyn chwalebny i swego rodzaju zasługę tylko wówczas, gdy wymaga ono przezwyciężenia szczególnych przeszkód albo wyróżnia się na negatywnym tle społecznym (resp. rzeczywistości wychowawczej).

Ze względu na teorię skutku przechodniego czynu dobrego zastosowanie go w postaci supererogacji w praktyce życia szkolnego może napotykać przeszkody. Współczesna młodzież bowiem, ze względu na szczególny rodzaj postmodernistycznej kulturowej opresji, sama staje się agresywna, cyniczna i niedostępna w przyjmowaniu dobra, zwłaszcza ze strony wychowawców i zwłaszcza dobra jako „czegoś więcej”. Współczesny „globalny nastolatek" doskonale obywa się przecież bez drogowskazów moralnych, sam dla siebie będąc miarą wszystkiego. Nie oznacza to jednak, że jego wewnętrzne ,ja" nie tęskni za nimi. Pokonanie szczególnych przeszkód jawiących się jako opór i negacja dobra, a także banalizacja zła przez uczniów, można uznać za swego rodzaju zasługę i czyn nadobowiązkowy, zwłaszcza jeśli wychowawca zechce uznać skutki nieprzechodnie tego czynu.

Jak widać, uznanie dobra jako czynienie „czegoś więcej” w praktyce aksjologii wychowawczej nie jest sprawą prostą, zbliża się do ideału i jako takiego nie można go oczekiwać od wychowawcy. Podzielenie się dobrem z wychowankiem nie może opierać się na ścisłym warunku ,powinieneś”, lecz na zaproszeniu „możesz”. Jeśli jednak przyjmiemy, że deontyczna sfera moralności jest często ujmowana jako sfera opisująca minimalne warunki moralności, wymagania bazowe moralności społecznej, podczas gdy sfera aksjologiczna zorientowana jest na wyższe ideały ${ }^{31}$, to wówczas agatologia jako pedagogia maksymalnego uczłowieczania człowieka może uznać supererogację jako jeden z warunków możliwości wychowania.

Poczynione w powyższym fragmencie wypowiedzi uwagi, dotyczące możliwości uznania dobra jako czynu supererogacyjnego, lokowałyby je na „pograniczu”, w przestrzeni między czysto deontologicznymi imperatywami a empirycznymi, przygodnymi, doświadczeniowymi okolicznościami etyki. Pedagogia agatologiczna, określana bowiem między innymi przez ideę ,wychowania dobrego człowieka” i Tischnerowską zasadę „poznać i wybrać dobro - oto klucz do rodzenia siebie", buduje w duchu „słabej ontologii” pomost pomiędzy teorią etyczną a moralnością opartą na doświadczeniu.

31 Tamże, s. 173. 
Dobro jako „coś więcej” jest, jak się wydaje, nieodzownym pojęciem naszego myślenia, przynajmniej tak długo, jak długo nasza potoczna świadomość zmuszać nas będzie do mówienia o czynach stanowiących zasługę, a to znaczy: chwalebnych ${ }^{32}$.

\section{Uwagi końcowe}

Rozpoznana w powyższej wypowiedzi zasada liberalnej filozofii wychowania J. Tischnera mówi wprost: wychowanie zakłada wolność. W sprawach dla wychowanka najważniejszych, bo najbardziej osobistych - uczeń musi mieć przestrzeń wolnego wyboru. Celem wychowania nie jest ukształtowanie wychowanka w duchu bezkrytycznej lojalności dla autorytetu wychowawczego i wydawanych przez niego rozporządzeń. Bardzo często żąda się od wychowanka posłuszeństwa dla prawa tylko dlatego, że jest prawem. Uważa się, że tylko takie przepisy są obowiązujące, które są oparte na wartościach prawnych, religijnych czy etycznych. Legalizm wychowawczy, zdaniem Tischnera, przynosi żałosne skutki w wychowaniu, gdyż człowiek wychowany w duchu tak rozumianej lojalności do prawa może być też głęboko nieetycznym. „W takiej osobie zostało podcięte jego naturalne wyczucie wartości etycznych. Na pewne wartości nie będzie on reagować w ogóle, a na inne w sposób spaczony, pozostawiając poza zasięgiem swego zainteresowania szereg spraw człowieka jako zupełnie niepodlegających procesowi wychowania lub nadając sztuczne znaczenie sprawom małej wagi" ${ }^{33}$.Tak rozumiany mechanizm wychowawczy narusza tezę o wolności człowieka. Uznanie wolności to przyznanie, że wychowanie jest ryzykiem, że jego rezultaty są prawdopodobne, a nie pewne. Legalizm wychowawczy narusza tezę o obiektywności wartości etycznych. W efekcie pozostaje tylko nauka posłuszeństwa, będącego najczęściej jedynie umiejętnością dostosowania się do panującego chaosu. Tischner był zdania, że w wychowaniu chodzi właśnie o to, ażeby człowiek stawał się coraz bardziej człowiekiem - o to, ażeby bardziej, a nie tylko więcej umiał, aby więc poprzez wszystko, co ma, co posiada, umiał bardziej i pełniej być człowiekiem, to znaczy, ażeby również umiał bardziej być nie tylko z drugim, ale i dla drugich ${ }^{34}$.

\footnotetext{
32 Zob. A. Kaniowski,dz. cyt., s. 385.

${ }^{33}$ Z problematyki wychowania chrześcijańskiego,www.teologia.alauda.pl

34 J. Tischner, Myślenie, s. 482.
} 
Wolność jest podstawową wartością, dlatego wychowanie sprowadza się do prawidłowego korzystania z niej. Wolność to odpowiedzialność za siebie i innych. „Człowiek zniewolony to człowiek niedojrzały, a człowiek niedojrzały jest nieodpowiedzialny i niezdolny do samodzielnego życia" ${ }^{35}$. Im więcej dajemy drugiej osobie przestrzeni, ułatwiamy jej dokonywanie wyborów, tym szybciej nabierze ona mądrości życiowej i nauczy się odpowiedzialności za swoje czyny. Bardzo często wychowawcy łamią tę zasadę i narzucają swoje zdanie wychowankowi, przez co zatrzymują jego rozwój na etapie wczesnego dzieciństwa. Jak pisał Tischner:

Problemem najciekawszym, najpiękniejszym jest problem jeden: w jaki sposób człowiek może obudzić w drugim człowieku poczucie wolności. Bo zazwyczaj zastanawiamy się nad tym, co ja powinienem zrobić, żeby drugim tak, a nie inaczej pokierować. Ale pokierować drugim to znaczy zagrać z nim w jaką́ grę, może nawet zapanować nad nim. Tymczasem najgłębszym problemem wychowawczym nie jest to, w jaki sposób panować nad człowiekiem, ale w jaki sposób obudzić w nim człowieczeństwo. A człowieczeństwem jest wolnośćc ${ }^{36}$.

\section{Freedom as a Fundamental Premise of Jozef Tischner's Liberal Philosophy of Education (Summay)}

The aim of the paper is to raise awareness of ethical a priori in upbringing, in which the derivativeness or incompleteness of the human senses of being projected by it are often forgotten. The article answers the question: what must happen within everyday concern about a child, for a turn to be made in a child towards discovering himself as a good person, and that ethical a priori is recognized as an upbringing towards freedom principle. According to Tischner, in the sphere of upbringing towards freedom, there are four paths (transgression, transcendence, approximation, supererogation), which a child can follow, and a teacher can join him, if they only want to develop in themselves the potentiality to do good and bring up in good.

Keywords: freedom, transgression, transcendence, approximation, supererogation

${ }^{35}$ S. Szary, Filozofia wychowania Józefa Tischnera, „Zeszyty Naukowe Szkoły Wyższej Przymierza Rodzin w Warszawie. Seria Pedagogiczna" 3 (2009), s. 78.

${ }^{36}$ Por. W. Bereś, A. Więcek, Tischner-życie w opowieściach, Warszawa 2008, s. 9. 


\section{Wolność jako fundamentalna przesłanka liberalnej filozofii wychowania Józefa Tischnera (Streszczenie)}

Celem wypowiedzi jest uświadomienie etycznego a priori w wychowaniu, w którym nader często zapomina się o pochodności czy niezupełności projektowanych przez nie sensów bycia człowieka. Artykuł odpowiada na pytanie: co musi wydarzyć się w ramach codziennego zatroskania o wychowanka, żeby mógł dokonać się w nim zwrot do odkrywania siebie jako człowieka dobrego, a owo etyczne a priori ujmuje się w formie zasady wychowania do wolności. $\mathrm{W}$ przestrzeni wychowania do wolności wyróżnia się za Tischnerem cztery ścieżki (transgresje, transcendencję, aproksymację, supererogację), którymi może podążać wychowanek, a wraz z nim wychowawca, jeśli tylko będą chcieli rozwijać w sobie potencjalność czynienia dobra i wychowania w dobru.

Słowa kluczowe: wolność, transgresja, transcendencja, aproksymacja, supererogacja 
